\title{
Redescription and notes on the natural history of the arboreal tarantula Iridopelma seladonium (Araneae: Theraphosidae: Aviculariinae)
}

\author{
Lina M. Almeida-Silva ${ }^{1}$; Agustín Camacho ${ }^{2}$; Antonio D. Brescovit ${ }^{\text {; }}$ Sylvia M. Lucas ${ }^{1} \&$ Tania K. Brazil ${ }^{3}$ \\ 1 Laboratório de Artrópodes, Instituto Butantan, Butantan. Avenida Vital Brazil, 1500, 05503-900 São Paulo, São Paulo, \\ Brasil.E-mail: linamas@gmail.com; adbresc@terra.com.br; sylvialucas@butantan.gov.br \\ ${ }^{2}$ Laboratório de Herpetologia, Departamento de Zoologia, Instituto de Biociências, Universidade de São Paulo. \\ Caixa Postal 11461, 05422-970 São Paulo, São Paulo, Brasil. E-mail: agus.camacho@gmail.com \\ 3 Laboratório de Animais Peçonhentos, Universidade Federal da Bahia. Avenida Ademar de Barros, Ondina, \\ 40170-115 Salvador, Bahia, Brasil. E-mail: taniabn@ufba.br
}

\begin{abstract}
Iridopelma seladonium (C.L. Koch, 1841) (Theraphosidae, Aviculariinae) is a very rare, colorful and small tarantula found in the Atlantic Rainforest in Bahia and Sergipe. The original description of this species was based on a single female and no illustrations of reproductive organs were presented. After we collected several specimens identified as I. seladonium, we decided to redescribe this species and discovered that the male, previously described as belonging to this species, was misidentified by Mello Leitão (1923). Thus, in this paper the male of I. seladonium is newly described and the reproductive organs of male and female are described and illustrated in detail. Notes on the behavior and natural history of $I$. seladonium are presented based on the observation of live specimens in the field and in captivity. An immature of I. seladonium was observed constructing a hinged retreat with silk and little pieces of bark, a behavior not previously seen for other Aviculariinae. Two courtship events were observed and photographed, leg tapping and palpal drumming of the male on female's body and dorsum-ventral movements of the female's abdomen while the male was inserting the embolus were documented to Aviculariinae for the first time. The courtships and mating lasted almost two minutes.
\end{abstract}

KEY WORDS. Behavior; spiders; taxonomy.

RESUMO. Redescrição e notas sobre a história natural da tarântula arbórea Iridopelma seladonium (Araneae: Theraphosidae: Aviculariinae). Iridopelma seladonium (C.L. Koch, 1841) é uma tarântula pequena, rara e colorida encontrada na floresta Atlântica dos estados da Bahia e Sergipe. A descrição original desta espécie foi baseada numa única fêmea e nenhuma ilustração de seus órgãos reprodutivos foi apresentada. Após coletarmos alguns espécimes identificados como I. seladonium, decidimos redescrever esta espécie e descobrimos que o macho descrito por Mello-Leitão (1923) havia sido erroneamente identificado como pertencente a esta espécie. Assim, neste artigo, é descrito pela primeira vez, o macho de I. seladonium e pela primeira vez as genitálias do macho e da fêmea são detalhadamente ilustradas. Notas sobre o comportamento e a história natural de $I$. seladonium são apresentadas baseadas em dados de animais vivos observados no campo e em cativeiro. Foi observado um imaturo de I. seladonium construindo um abrigo convexo com pequenos pedaços de casca de árvore, comportamento desconhecido em Aviculariinae. Duas cortes foram observadas e fotografadas. Os comportamentos de tamborilar com as pernas; tamborilar com os pedipalpos do macho sobre o corpo da fêmea; e movimentos dorso-ventrais, do abdômen da fêmea, durante a inserção do êmbolo, são registrados pela primeira vez em Aviculariinae. $O$ tempo médio de duração da corte e da cópula foi de aproximadamente dois minutos.

PALAVRAS-CHAVE. Aranhas; comportamento; taxonomia.

The spider family Theraphosidae Thorell, 1870 includes, to date, 906 species distributed throughout 112 genera (PlatNick 2008). Of these, 57 are recorded from the Neotropical region with almost 500 species distributed throughout South America. These spiders are commonly known as "tarantulas" and are trade as pets. For most of these species, the biology, ecology and systematics are very poorly known (Costa \& Perez-Miles
1992, 2002, DiAs \& BRescovit 2003).

In South America, the family is represented by three subfamilies: Aviculariinae, Ischnocolinae and Theraphosinae. Theraphosinae and Ischnocolinae are the largest, comprising 52 genera. Aviculariinae includes only five genera: Avicularia Lamarck, 1818, Ephebopus Simon, 1892, Iridopelma Pocock, 1901, Pachistopelma Pocock, 1901 and Tapinauchenius Ausserer, 1871. 
Iridopelma includes, to date, only three species: I. hirsutum (Pocock, 1901); I. seladonium (C.L. Koch, 1841) and I. zorodes (Mello-Leitão, 1926) (Platnick 2008). All species are known to be essentially arboreal and can be found in Atlantic forests of north and northeastern Brazil (STRIFFLeR 2004: 11).

Iridopelma seladonium, the object of this study, is a very rare, small and bright colored tarantula. It is known only from Brazilian Atlantic rainforest in the states of Bahia and Sergipe which, according to "World Wildlife Fund - WWF" and Brazilian governmental agencies, is a region of great importance for the conservation of Atlantic Rainforest vertebrates (MмA 2000). It is also critically endangered area and less than five percent of the original forest remains, being considered third level of priority among Brazilian conservation categories.

Originally described by C.L. Косн (1841) in Mygale Latreille, 1802, it was transferred to Typhochlaena C.L. Koch, 1850, by C.L. KocH (1850) and posteriorly to Avicularia Lamarck, 1818, due to the synonymization of both genera (SimON 1892). MELlo-LeITão (1923) erroneously reestablished Typhochlaena without removing the type species, Typhochlaena caesia C.L. Koch, 1842, from Avicularia. He also described what is here determined to be a misidentification of the male of T. seladonium. Even though most authors did not accept Mello-Leitão's reestablishment and continued to treat Typhochlaena as a junior synonym of Avicularia. SMIth (1993), following RAven (1985), revalidated Iridopelma, redescribed I. hirsutum Pocock, 1901 and transferred T. seladonium to this genus, where it remains to date (Platnick 2008).

In this paper, we present a redescription of the female and the first description of the male of I. seladonium. In addition, we present a brief discussion on its taxonomic position and preliminary data on the biology based on observations of live specimens in the field and in captivity.

\section{MATERIAL AND METHODS}

The material examined is deposited in the following institutions (abbreviation and curator in parentheses): Centro de Ecologia e Conservação Animal da Universidade Católica do Salvador, Salvador (ECOA, M.C.L. Peres), Instituto Butantan, São Paulo (IBSP, A.D. Brescovit) and Museu de Zoologia da Universidade Federal da Bahia, Salvador (MZUFBA, T.K. Brazil).

All measurements are in millimeters. The male palp was illustrated in prolateral and retrolateral view using a Leica MZ12,5 stereomicroscope with camera lucida. Female spermathecae were dissected and submerged in clove oil to study internal structures. Abbreviations used throughout the text: (AME) anterior median eyes, (ALE) anterior lateral eyes, (PME) posterior median eyes, and (PLE) posterior lateral eyes.

For SEM studies dead spider material was dried using the heat of $30 \mathrm{~W}$ eletric lamp, mounted on stubs, sputter coated with a $30 \mathrm{~nm}$ gold layer and examined at $15 \mathrm{kV}$ in a JEOL (JSM 840 A) scanning electron microscope from the Laboratório de Microscopia Eletrônica, Departamento de Física Geral, Instituto de Física, Universidade de São Paulo (USP).
Live material: one female and one immature, collected at Fazenda Camurujipe, Mata de São João, Bahia northeastern Brazil, and one male donated to the "Núcleo Regional de Ofiologia e Animais Peçonhentos (NOAP)" from Universidade Federal da Bahia (UFBA). These specimens were later deposited in MZUFBA under the numbers 2062, 2394 and 2060, respectively.

Spiders were maintained separately, in round plastic pots (15 cm diameter $x 15 \mathrm{~cm}$ high), at room temperature, with tree branches, wet cotton and fed with Tenebrio sp. (Coleoptera: Tenebrionidae) larvae and adults of Ceratitis capitata (Weidemman, 1824) fruit flies (Diptera) at the UFBA. Mating was observed ad libitum, in two sessions, in alternate days, with the same couple. The first session started at 11:00 am and the second started at 4:30 pm, as soon as the male was placed on the board of the female's cage and ended when it was removed. Each mating event lasted approximately eight minutes. Only the second mating event was photographed, using a Nikon F50 reflex camera with flash.

\section{RESULTS}

\section{Iridopelma seladonium (C.L. Koch, 1841)}

Mygale seladonia C.L. Koch, 1841: 39, fig. 716 (Female holotype from the state of Bahia, Brazil, deposited in ZMB 2033, dry collection, examined by means of a picture of the type specimen kindly sent by J. Dunlop, Fig. 2).

Typhochlaena seladonia; C.L. Koch, 1850: 75.

Avicularia seladonia; Simon, 1892: 171; Petrunkevitch, 1911: 50; Petrunkevitch, 1939: 288; Bonnet, 1955: 832.

Iridopelma seladonium; Smith, 1993: 15 (Tranf. from Avicularia); Platnick, 2008.

Diagnosis: Iridopelma seladonium differs from the remaining species of Iridopelma by the exuberant coloration (Figs 3 and 4) and absence of tibial apophysis on the legs I and II in males. It differs from I. hirsutum by the male palpal bulb sub triangular in I. seladonium (Figs 5 and 6) while apple-shaped in I. hirsutum (SмIтн 1993: 15 fig. 7), by the narrower embolus base (Figs 5 and 6) and by the female's globular spermathecae with rounded apex (Fig. 7), bifid in I. hirsutum (SмiтH 1993: 15 fig. 10).

Description: male (MZUFBA 2060) Coloration as in figure 3, cephalic area metallic dark green, continuing as a thin line in the middle of the carapace and enlarging on posterior border. Pale yellow setae covering the lateral border of the carapace. Chelicerae, endites and sternum covered by metallic dark green setae. Palps and all leg articles metallic navy blue. Abdomen with a black anterior line followed by five black transversal lines and a median black. Between the first and second line a pair of pink spots cover all the space, turning yellow towards the center. In ethanol the legs appear light brown with bright hairs. Total length: 12.38 . Carapace: 5.43 long, 5.52 wide. Abdomen: 6.96 long, 4.48 wide. Sternum: 4.3 long, 3.5 large. Eye tubercle: 1.38 long 0.78 wide. Eye measurements: AME 0.21, ALE 0.23, PME 0.18 and PLE 0.19. AME rounded, ALE, PLE and

Revista Brasileira de Zoologia 25 (4): 728-736, December, 2008 

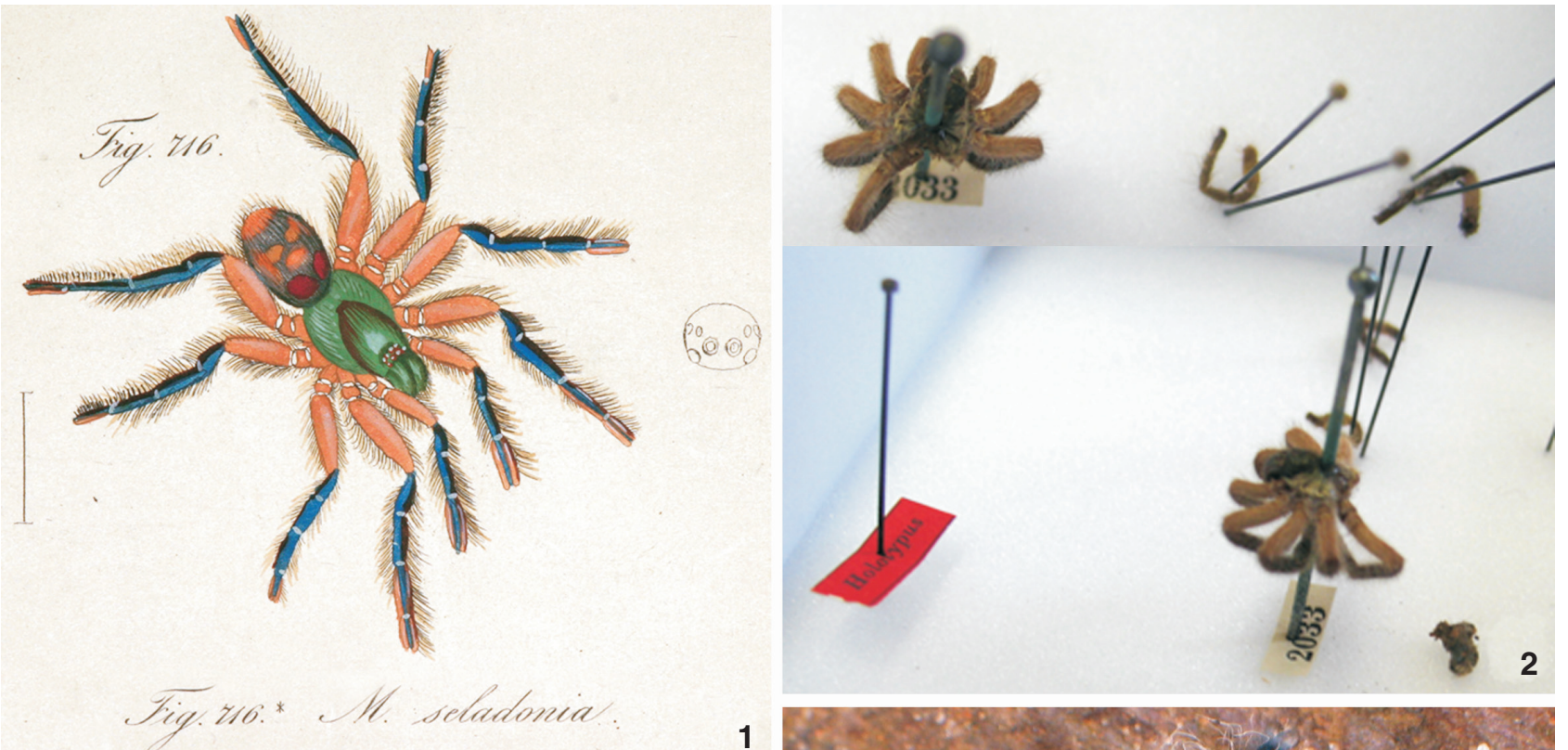

1
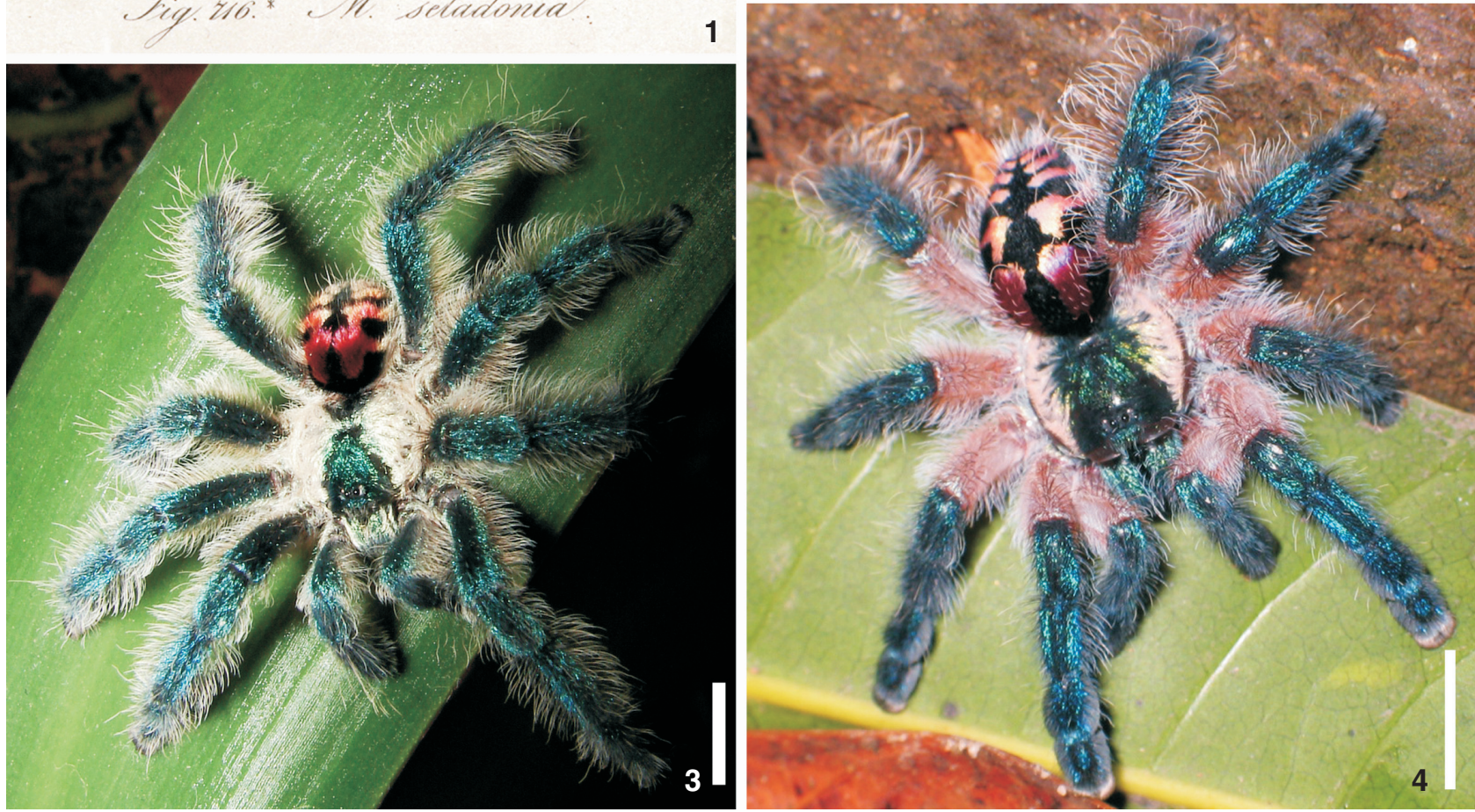

Figures 1-4. (1) Original illustration from C.L. Koch's (1841) description; (2) photos from type-material; (3) male habitus; (4) female habitus. Scale bars: $5.00 \mathrm{~mm}$.

PME ovals. Cephalic area low and thoracic striae shallow. Fovea: transversal, deep, 0.88 wide. Chelicerae basis (without fang): 2.00 long, with seven promarginal teeth (Fig. 9). Labium: 0.56 long 1.1 wide, with 58 rhomb cuspules on anterior half. Endites: 2.31 long, 1.09 wide, with 23-25 cuspules in the posterior corner. Labiosternal suture thin. Sigilla: anterior pair inconspicu- ous and the other two pairs small and conspicuous situated near the sternal margin. Tarsi I-IV scopulate, tarsus IV with a line of spiniform setae dividing the scopulae longitudinally. Metatarsi I-II scopulate, III 2/3 scopulate and IV only distally scopulate. Spines absent on all legs. Palp measurements: femur 4.1/patella 2.25 /tibia 3.4/cymbium 0.75 /total 10.5 ; leg mea-

Revista Brasileira de Zoologia 25 (4): 728-736, December, 2008 


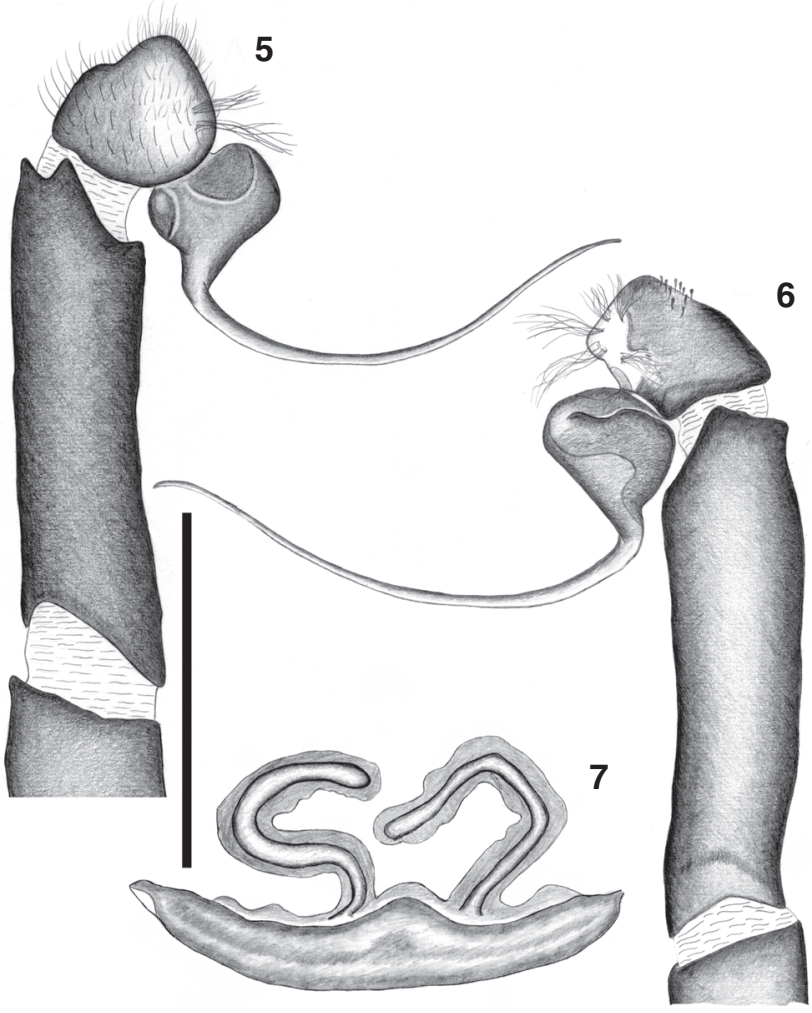

Figures 5-7. (5) Male left palp retrolateral view; (6) male left palp prolateral view; (7) female spermathecae. Scale bar: $0.5 \mathrm{~mm}$.

surements I: femur 6.4/patella 3.0/tibia 4.7/metatarsus $4.7 /$ tarsus 2.4/total 20.7; II: 5.85/2.95/4.65/3.85/2.05/19.35; III: 5.1/ 2.16/3.96/3.76/1.96/16.94; IV: 6.3/2.6/5.1/4.9/2.04/20.93. leg formula: 4123 . Trichobothria with clavate hairs at the apex of the cymbium.

Female (MZUFBA 1246) coloration as in male except leg and palpal femora pink. Total length: 16.72. Carapace: 7.84 long, 7.52 wide. Abdomen: 8.88 long, 5.13 wide. Cephalic area and thoracic striae as in male. Labium: 1.04 long, 1.56 wide with 80 rhomb cuspules (Fig. 10). Endites: 3.31 long, 1.72 wide with 60 rhomb cuspules. Chelicerae basis (without fang): 4.75 long, with seven prolateral teeth (Fig. 11). Fovea: transversal 1.64 wide. Ocular area: 1.88 long, 1.13 high. Eye measurements: AME 0.23, ALE 0.30, PME 0.30, PLE 0.45. AME rounded ALE, PME and PME oval. Tarsi I-IV scopulate (Fig. 12), tarsus IV with a line of spiniform setae in the middle of the scopulae. Clavate trichobothria (Figs 12-14) on the dorsal surface of all tarsi. Metatarsi with truncated hairs (Fig. 15), I-III scopulate and IV only distally scopulate. Spines absents on all legs. Palp measurements: femur 4.46/patella 2.8/tibia 2.84/tarsus 3.25. leg measurements I: femur 5.3/patella 3.5/tibia 4.0/metatarsus 3.31/ tarsus $1.88 /$ total 17.99 ; II: 5.19/3.5/3.69/3.04/1.88/17.13; III: 4.5/1.18/3.85/2.85/1.68/14.06; IV: 5.9/3.6/4.9/4.25/2.1/20.75. leg formula 4123 .
Variation: two males, total length: 11.63-12.38, carapace length: 5.43-5.71, femur I length: 6.4-6.98; seven females, total length: 7.97-18.00; carapace length: 4.04-6.37; femur I length 3.56-7.00.

Other material examinated: Brazil, Sergipe: Santa Luiza do Itanhy (Mata do Crasto, $11^{\circ} 23^{\prime} \mathrm{S}, 37^{\circ} 24^{\prime} \mathrm{W}$ ), 1 immature, 06/XII/ 1996, A.D. Brescovit leg. (IBSP 15372); Bahia: Mata de São João (Fazenda Camurujipe,12030'5"S, 38²'19"W), 1 female, 1 immature, 25/X/2004, A. Camacho leg. (MZUFBA 2062, 2394); Camaçari (Guarajuba, 1241'51"S, 38¹9'27”W), 1 female, 18/ XI/1991 (MZUFBA 1536); 1 female, 21/V/1981, T.K. Brazil leg. (IBSP 7907); Lauro de Freitas (1253'40"S,/38¹9'38”W), 1 female, 03/06/1992, (MZUFBA 1246); Salvador, (Saboeiro, $12^{\circ} 58^{\prime} 16^{\prime \prime}$, 38 30'39"W), 1 male, 11/XII/2004, R. Burger leg. (MZUFBA 2060); (Cabula), 1 male, X/2005, T.K. Brazil leg. (MZUFBA 84); 1 female, IX/90 (MZUFBA 1530); 1 female, 04/ 02/2004, (ECOA 685); (Alphaville), 1 female, 11-29/XI/2001, G.G. Montigelli leg. (IBSP 9718); Ibicoara (13²4'38"S, 38³0'39”W), 1 female, 9/X/2004, T.K. Brazil leg. (MZUFBA 1941).

Remarks: the original description of I. seladonium is based on a female specimen and is poorly informative. However, it includes a colored illustration (Fig. 1), which enables the correct identification of the species. The bright coloration pattern of this species leads us to investigate the different types of hairs (Figs 16-19) related to this metallic coloration. We were able to conclude that this coloration is not related exclusively to the morphology of the hair (structural color) but also to its chemical composition (pigment related color). The urticating hairs type II found (Fig. 16) were not related to bright coloration. Studies on chemical composition of colors in spiders (OXFORD \& GiLlesPie 1998) indicate that the pink (Fig. 17) and black hairs from the abdomen and the pale yellow hairs of the carapace board (Fig. 18), should be related to ommochromes. The green and blue hairs of the legs and carapace are a result of bilins, but differences in hair morphology cause the structural color and are related to the metallic brightness (OxFord \& GILlespie 1998), most conspicuous in the blue and green scale hairs (Fig. 19) of the legs and carapace. We do not discard the possible interaction between this component and the guanine present on the cuticle and studies on color pigments and hairs of this species are encouraged.

The collection of a male (MZUFBA 2060) with the same coloration pattern as the females of $I$. seladonium except for the femora and without tibial apophysis on legs I and II allowed us to conclude that the male described by MeLLo-Leitão (1923) is not conspecific with the females of I. seladonium and belongs to a different species. The relationships between the species of Iridopelma will only be understood after the genus undergoes a cladistic analysis, probably including another species of Aviculariinae, which might shed some light on the evolution of the male tibial apophysis.

Distribution: known only from Brazil: states of Sergipe and Bahia.

Revista Brasileira de Zoologia 25 (4): 728-736, December, 2008 

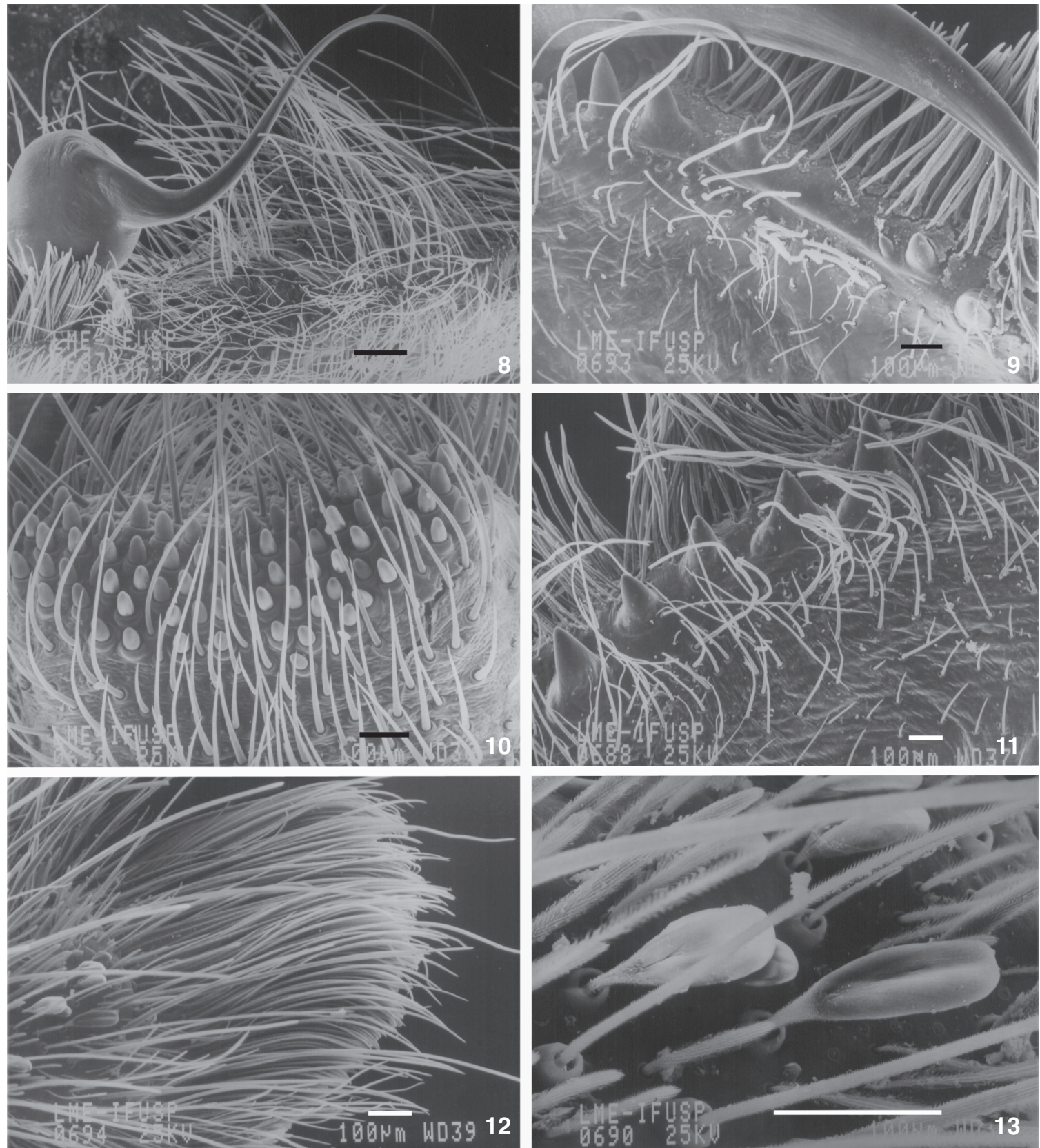

Figures 8-13. (8) Male palp prolateral view; (9) male chelicerae promarginal view; (10) female labium with cuspules; (11) female's teeth from chelicerae promargin; (12) female tarsus showing scopulae and clavate Tricobothria; (13) clavate hairs from Tricobothria in details. Scale bars: $100 \mu \mathrm{m}$.

\section{Natural history}

Sexual dimorphism: I. seladonium shows remarkable sexual dimorphism in adults defined by the coloration of its femora: pink in females (Fig. 4) and uniform in males (Fig. 3). The only immature observed had the same coloration as the females. As it died prematurely, we could not determine its sex.
Habitat and foraging: all specimens of I. seladonium were found inside or near lowland Atlantic rainforest fragments of northern coastal Bahia and in disturbed fragments in the metropolitan area of Salvador. Small remnants of Atlantic Rainforest still stand dispersed along the coast of Brazil, at less than $100 \mathrm{~m}$ above sea level. Within the known distribution area of $I$.

Revista Brasileira de Zoologia 25 (4): 728-736, December, 2008 

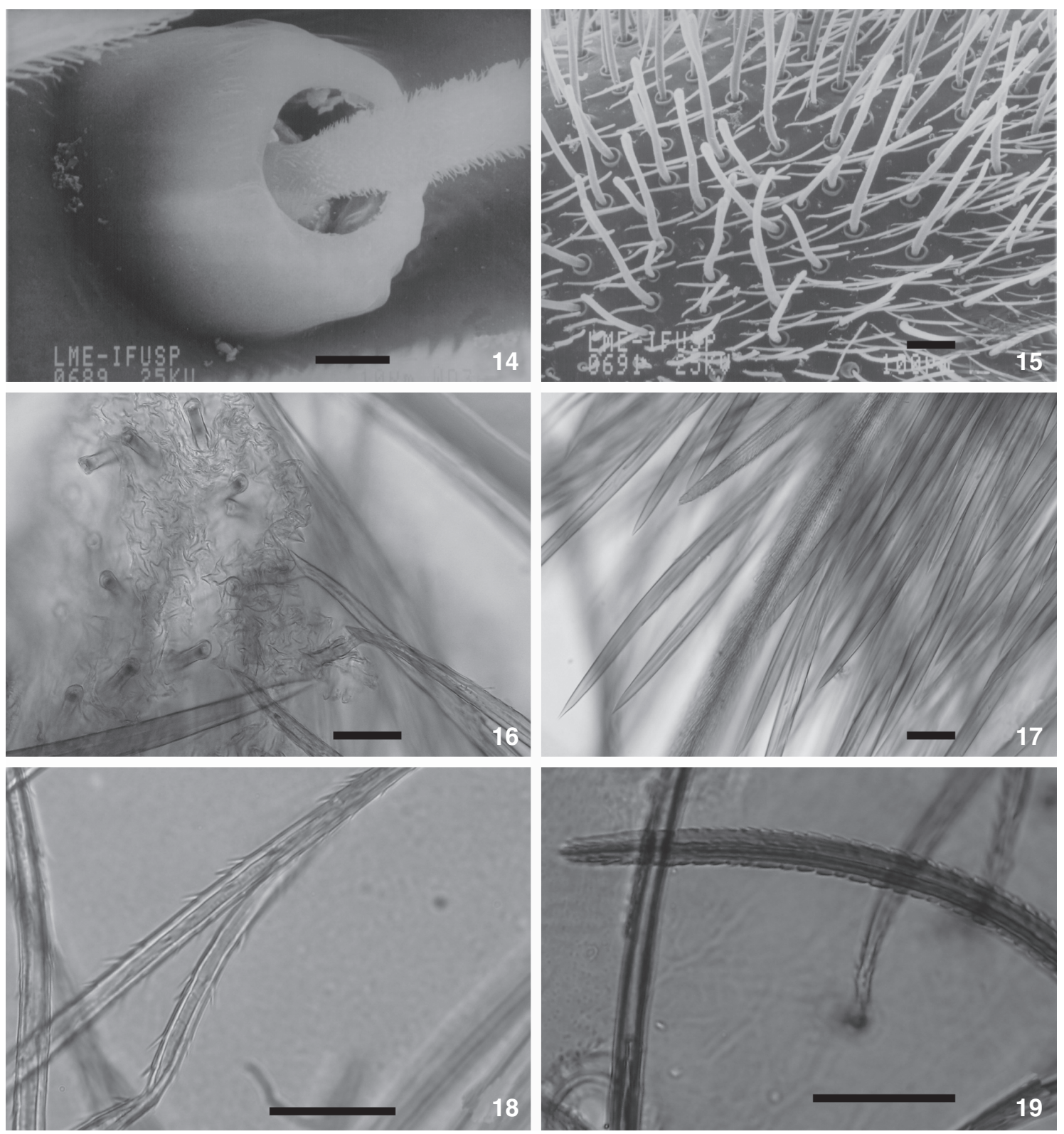

Figures 14-19. (14) base of a Trichobothrium; (15) Truncate hairs from metatarsus I; (16) base of the urticating hairs; (17) hairs of the pink area of the abdomen; (18) pale yellow hairs of the border of the carapace; (19) bright green scale hairs from carapace. Scale bars: (14) $10 \mu \mathrm{m} ;(15,18,19) 100 \mu \mathrm{m} ;(16,17) 50 \mu \mathrm{m}$.

seladonium, annual temperature varies from $21-26^{\circ} \mathrm{C}$. Annual pluviosity reaches $2000 \mathrm{~mm}$ and rainfall is more concentrated between March and July (INMET 2006). The few observations of $I$. seladonium in its natural habitat were made in mature forests and suggest that they live on the vegetation. A male was observed on lianas at $1.50 \mathrm{~m}$ high and two females were observed under tree bark. The female and the immature maintained in captivity (MUZUFBA 2062 and 2394) were found on the bark of different trees at two meters high, and an additional immature was collected by PINTO-Leite et al. (2008) under low leaves of a bush. Three males (MZUFBA 2060, MZUFBA 84 and one additional uncollected) were found walking inside houses near disturbed forest remnants in the metropolitan area of Salvador.

The male MZUFBA 2060 showed high activity, spending a lot of time walking during the day and night and hardly feeding. Another male (MZUFBA 84) presented the same behavior

Revista Brasileira de Zoologia 25 (4): 728-736, December, 2008 

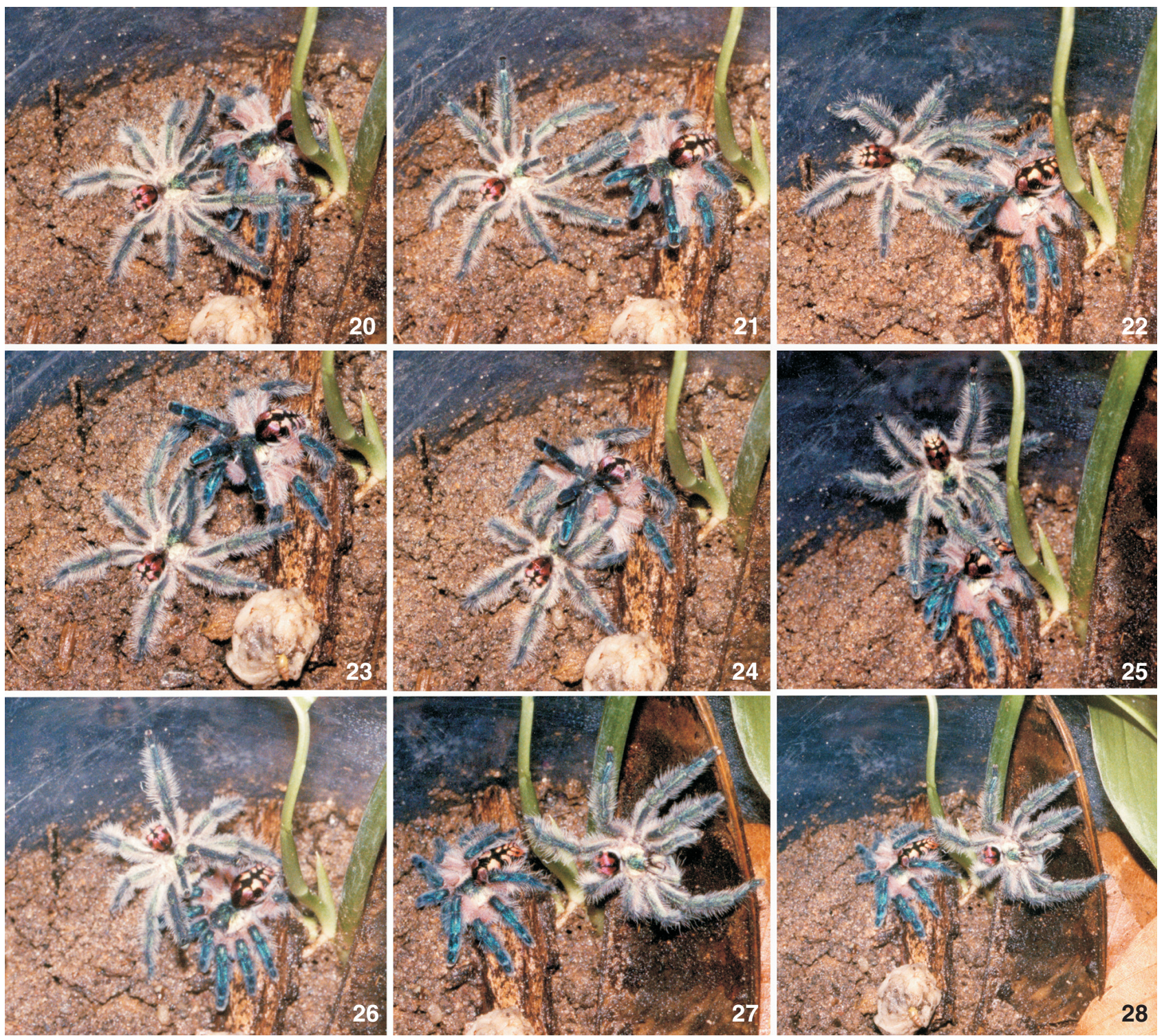

Figures 20-28. (20) First contact between male and female with leg tapping; (21) male starts to tapping above female's body; (22) continuing tapping over her side until completing a turn around her; (23) male starts to rise the female; (24) time of drumming on her genital area followed by palpal insertion; (25) male start to drumming over female's abdomen; (26) continuing the drumming over her carapace; (27) female shrink while male starts grooming; (28) male continue grooming for at least five minutes.

and died a few days after it was received. An adult female (MZUFBA 2062) was maintained in captivity in the NOAP. During the day, they rested under pieces of bark provided as shelters, being more active at night. It fed on offered flies and little mealworms and repeatedly attached silk to the walls of the cage.

The immature specimen (MZUFBA 2394), a small spider with less than 1.0 centimeters of total length was found in October, 2004 a few meters away from the previous female (MZUFBA 2062). In IV/2005, the immature, who had doubled in body size, built an extremely cryptic refuge, with thin pieces of bark, fixed with silk from the inside, in the shape of an overturned cup. The retreat was nearly the same size as the animal, and one side was not fixed to the substrate, allowing the animal to open it from the inside. We rarely saw the spider outside of the retreat once it was constructed. The animal started to feed only on prey that touched the refuge, quickly seizing and taking them inside. In September, 2005, the animal left its retreat, stopped feeding and died in October, 2005, after an unsuccessful ecdysis.

Revista Brasileira de Zoologia 25 (4): 728-736, December, 2008 
Courtship and mating behavior (Figs 20-28): the female was collected one month before the male brought to the NOAP. Two weeks after the arrival of the male we placed it inside the female's cage. We observed two mating events of the same couple (MZUFBA 2060 e 2062) and the behavioral repertory was as follows: As soon as the male came into contact with the female's silk, he started to walk faster, tapping with leg I (Fig. 20). When they made contact, the male started drumming over the female's body, first on the cephalothorax, from the front (Fig. 21), from on side (Fig. 22) and from behind over her abdomen for 20 seconds approximately. When he completed a whole turn around her body, the male started to gently raise her forelegs and palps (Fig.23) with female's cooperation. With the leg I, the male held the female palp and leg I and using leg II he surrounded the female body keeping her leg II away. At this moment, the male started drumming on her genital area followed by eight palpal insertions, which were few, brief and regularly alternated (Fig. 24). While the male was inserting the embolus, the female moved her abdomen from anterior to posterior, rhythmically. After approximately 20 seconds, the male ceased palpal insertion, started to drumming over the female's body and ran away from her (Fig. 25), while the female recoiled, putting her legs close to the body (Fig. 26). Later, on a nearby leaf, he started grooming himself (Fig. 27) for a long period (Fig. 28). Five minutes later the female started grooming herself as well. Only one mating attempt was observed in each session. The complete observation took almost nine minutes, courtship and mating took almost two minutes and the copulation lasted approximately 20 seconds.

After mating the male stopped feeding and two weeks later died. The female did not present any visible shift in behavior after mating, but she died during an unsuccessful ecdysis, before ovipositing.

\section{DISCUSSION}

The field notes related to the capture suggest that this species lives under structured tree bark or under low leaves, inside lowland Atlantic Rainforests. However, in their search for females, males can wander considerably long distances, being accidentally found inside houses hundreds of meters away from the nearest forest. Its geographical distribution extends from southern Bahia to the northern littoral of the state of Sergipe. Maybe because this region remains unstudied and extremely damaged by habitat destruction (only a few fragments, smaller than 5000 ha, remain). Thus, it has been relatively undervalued among the priorities for conservation of Atlantic Rainforests (Mma 2000). However, in the northern coast of Bahia several new and endemic species of invertebrates and vertebrates have been discovered, and recent inventories have resulted in many undetermined species and expansions of distribution ranges (e.g. Dias et al. 2002, CRUz et al. 2007, СAMACHO \& Rodrigues 2007, Pinto-Leite et al, 2008). Therefore, we highly encourage the study of its habitat requirements and abundance of as well as the enforcement of legal protection for its habitat in the northern littoral of Bahia.

In relation to the sexual behavior, the occurrence of leg tapping before the contact between male and female agrees with the idea that there are contact sex pheromones on the female silk, as proposed and observed by Costa \& Perez-Miles (1992, 2002) for Plesiopelma longisternale (Schiapelli \& Gerschman, 1942) (under Ceropelma Mello-Leitão, 1923 and by STRIFfler (2004) for Avicularia versicolor (Walckenaer, 1837).

Drumming over the female's body has been described in Mecicobothriidae (Costa \& Pérez-Miles 1998), and was observed in Avicularia versicolor by STRIFfLer (2004) unlike other theraphosids where this feature occurs only on the silk. HubERT (1998), reviewing GerhardT's (1911-1933) proposed a classification of female's cooperation and according with this $I$. seladonium females assumed the copulatory position, a behavior also observed in Avicularia avicularia (Linnaeus, 1758). Also, the duration of the copulation, the number of palpal insertions and the insertion behavior were also in accordance to that observed for A. avicularia (Huber 1998).

Female abdominal movements were synchronous to the palpal insertions agreeing with that observed for Mecicobothrium thorelli Costa \& Pérez-Miles, 1998.

The behavior of falling carapace down, commonly observed in Theraphosinae and Aviculariinae at the time of the sperm transfer was not observed in this species, leaving doubts about the existence of falling carapace down in I. seladonium.

\section{ACKNOWLEDGMENTS}

We wish to thank Cristina A. Rheims for revision of the English version and helpful suggestions on the manuscript, Hilton Japyassú for helpful suggestions on the manuscript and Jason Dunlop for comparing and take photos of the holotype. We also thank Fernando Marques from the Laboratório de Helmintologia Evolutiva, Universidade de São Paulo" for the use of the light microscopy equipment. This study was supported by Fundação de Amparo à Pesquisa do Estado de São Paulo (MS grant 06/05453-0 to LMAS) and Conselho Nacional do Desenvolvimento Científico e Tecnológico (grant 302148/20078 to $\mathrm{ADB})$.

\section{LITERATURE CITED}

BonNET, P. 1955. Bibliographia araneorum. Toulouse 2 (1): 1918.

Camacho, A.G.; M.T. Rodrigues. 2007. Dryadosaura nordestina (Squamata, Gymnophthalmidae): Geographic distribution. Herpetological Review 38: 218-219.

Costa, F.G. \& F. Pérez-Miles.1992. Notes on mating and reproductive success os Ceropelma longisternalis (Araneae, Theraphosidae) in captivity. The Journal of Arachnology 20: 129-133.

Costa, F.G. \& F. Pérez-Miles.1998. Behavior, life cycle and webs of Mecicobothrium thorelli (Araneae, Mygalomorphae, Mecicobothriidae). The Journal of Arachnology 26: 317-329. 
Costa, F.G. \& F. Pérez-Miles. 2002. Reproductive biology of Uruguayan theraphosids (Araneae, Theraphosidae). The Journal of Arachnology 30: 571-587.

Cruz, C.A.G; U. Caramaschi; M.F. Napoli. 2007. A new species of Chiasmocleis (Anura, Microhylidae) from the atlantic Rain Forest of northeastern Bahia, Brazil. South America Journal of Herpetology 2: 47-51.

Dias S.C. \& A.D. Brescovit. 2003. Notes on the behavior of Pachistopelma rufonigrum. Revista Brasileira de Zoologia 20 (1): 13-17.

Dias E. J. R., C. F. D. Rocha and D. Vrcibradic. 2002. New Cnemidophorus (Squamata: Theidae) from Bahia state, northeastern Brazil. Copéia 4: 1070-1077.

Huber, B. 1998. Spider's reproductive behaviour: a review of Gerhardt's work from 1911-1933, with implications for sexual selection. Bulletin of the British Arachnological Society 11 (3): 81-91.

InMET. 2006. Dados meteorológicos da estação de Ondina, Salvador-BA. Available online at: http://www.inmet.gov.br/ html/observacoes.php [Accessed: III.2006].

Косн, C.L. 1841. Die Arachniden. Nürnberg, Achter Band, p. 41-131, Neunter Band, p. 1-56.

Косн, C.L. 1850. Übersicht des Arachnidensystems. Nürnberg, Heft 5, p. 1-77.

MMA. 2000. Avaliações e ações prioritárias para a conservação da biodiversidade da Mata Atlantica e dos Campos Sulinos. Brasília, Ministério do Meio Ambiente, 40p.

Submitted: 13.V.2008; Accepted: 02.XII.2008.

Editorial responsibility: Claudio J.B. de Carvalho
Mello-Leitão, C.F. DE. 1923. Theraphosideas do Brasil. Revista do Museu Paulista 13: 1-438.

Oxford, G. S. \& R.G. Gillespie. 1998. Evolution and ecology of spider coloration. Annual Review of Entomology 43: 619643.

Petrunkevitch, A. 1911. A synonymic index-catalogue of spiders of North, Central and South America with all adjacent islands, Greeland, Bermuda, West Indies, Terra del Fuego, Galapagos, etc. Bulletin of the American Museum of Natural History 29: 1-791.

Pinto-Leite, C.M.; A.G. Camacho; T.K. Brazil. 2008. Non random patterns of spider composition in an Atlantic Rainforest . Journal of Arachnology 36: 448-452.

Platnick, N.I. 2008. The World Spider Catalog, version 8.5 (online). Available online at: http://research.amnh.org/ entomology/spiders/catalog81-87/INTRO1.html [Accessed: 09/V/2008].

RAven, R.J. 1985. The spider infraorder Mygalomorphae (Araneae): cladistics and systematics. Bulletin of the American Museum of natural History 182: 1-180.

SimON, E. 1892. Histoire naturelle des araignées. Paris, 1: 1256.

Sмiтh, A.M. 1993. Taxonomy focus. Journal of Britsh Tarantula Society 9 (1): 13-18.

Striffler, B.F. 2004. Die Martinique-Baumvogelspinne Avicularia versicolor + A. purpurea, A. minatrix und A. laeta. Münster, Natur und Tier-Verlag, 62p. 